\title{
Arbor cutis resulting from using topical imiquimod for treating actinic keratosis and squamous cell carcinoma in situ
}

\author{
Aktinik keratoz ve skuamöz hücreli karsinoma in situ tedavisinde topikal \\ imikimod kullanımına sekonder hiperkeratoz
}

\section{Gülsün Hazan Tabak, @ Neslihan Akdoğan, ๑ Gonca Elçin}

Hacettepe University Faculty of Medicine, Department of Dermatology, Ankara, Turkey

Keywords: Cutaneous squamous cell carcinoma, imiquimod, side effect

Anahtar Kelimeler: Skuamöz hücreli karsinom, imikimod, yan etki

\section{To the Editor}

Actinic keratosis is the precursor lesion for invasive squamous cell carcinoma (SCC) and SCC in situ. Clinically, SCC in situ manifests as well-circumscribed, hyperkeratotic, and reddish plaques. Topical imiquimod $5 \%$ is an off-label but frequently used treatment for SCC in situ.

We report a female patient, aged 83 years, with exaggerated hyperkeratotic plaques after applying imiquimod 5\% for treating SCC in situ. The patient presented to our dermatology outpatient clinic with small crusting lesions on her face that surfaced 5 years ago (Figure 1A). She denied pain, pruritus, burning, or stinging related to the lesions.

Dermatological examination revealed one filiform hyperkeratotic papule and one thick scaly plaque. Both lesions were located on an erythematous, thin plaque with a diameter of approximately $10 \times 10 \mathrm{~cm}$ in the right malar region (Figure $1 \mathrm{~B}$ ). Additionally, there were around 5-10 erythematous, thin plaques on the left and right malar regions.
Two separate 4-millimeter punch biopsies were taken from the previously mentioned filiform hyperkeratotic papule and thick scaly plaque located on the right malar region. The results of the biopsies showed actinic keratosis in the filiform papule and SCC in situ in the thick scaly plaque.

Topical imiquimod $5 \%$ was prescribed to be taken once daily for 5 days a week. In the sixth week of treatment, we observed large hyperkeratotic fissured plaques that tightly adhered to the base, covering the bilateral malar regions (Figure 1C, D).

Consequently, we discontinued imiquimod and put the patient on balsam of Peru ointment twice daily for 5 days. Following the removal of the hyperkeratotic plaques, we applied Centella asiatica extract and topical 5-fluorouracil treatments in turn, and the patient's lesions completely regressed (Figure 1E, F).

Imiquimod enhances the natural immunity by increasing the release of interferon gamma, tumour necrosis factor alpha, and interleukin-12 and by activating the Langerhans cells of

Address for Correspondence/Yazışma Adresi: Neslihan Akdoğan MD, Hacettepe University Faculty of Medicine, Department of Dermatology, Ankara, Turkey Phone: +90 3123051706 E-mail: nslakdogan@gmail.com Received/Geliş Tarihi: 08.07.2021 Accepted/Kabul Tarihi: 22.08.2021 ORCID: orcid.org/0000-0002-1137-5399

Cite this article as: Tabak GH, Akdoğan N, Elçin G. Arbor cutis resulting from using topical imiquimod for treating actinic keratosis and squamous cell carcinoma in situ. Turkderm-Turk Arch Dermatol Venereol 2021;55:206-7 


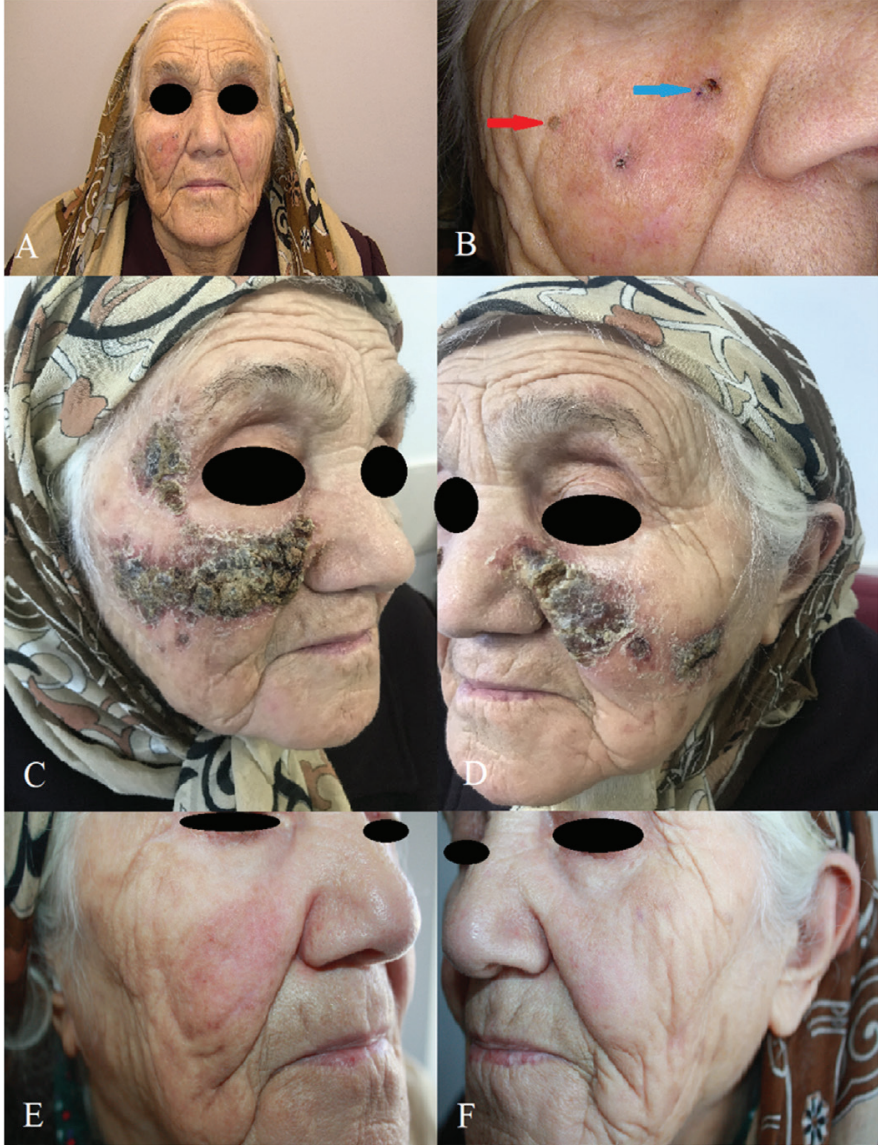

Figure 1. (A) Hyperkeratotic papules and plaques are denser in the right malar region. (B) Filiform hyperkeratotic papule (red arrow) and thick scaly plaque on the erythematous base (blue arrow). (C, D) Thick hyperkeratotic fissured plaques denser in the right malar region and tightly adhered to the base. (E, F) Regressed lesions following all treatment methods

the skin and acquired immunity by enabling the conversion of naive T-cells to Th1 ${ }^{1-3}$. Although topical imiquimod has not been proven in the treatment of SCC in situ, it has been successfully used for treating SCC in situ lesions, including lesions in sensitive areas such as the eyelids and nose ${ }^{4,5}$.

Many side effects were reported after the application of imiquimod, such as exudate formation, erosion, bleeding, tenderness, and, rarely, scar formation. The literature reported a hyperkeratotic plaque named "arbor cutis" that occurred secondary to using topical imiquimod to treat SCC in situ lesions with surgical margin positivity. The authors claimed that imiquimod causes excessive immune response in severely sun-damaged skin².

Based on the previously mentioned claim, we considered that imiquimod caused the mentioned lesions, which may be a mild type of irritant cytokine dermatitis ${ }^{6}$. Additionally, the retention hyperkeratosis due to corneocyte accumulation in the stratum corneum may affect the formation of these rough thick adherent scales.

To conclude, hyperkeratotic plaque formation is one of the side effects of topical imiquimod $5 \%$. The hyperkeratotic plaque formation, which clinically seems intimidating, is in fact an innocent side effect. Clinicians may be overconcerned about the formation of such hyperkeratotic plaques; however, the base under the plaques is extremely satisfying. Informed written consent was taken from the patient.

\section{Ethics}

Informed Consent: Informed written consent was taken from the patient.

Peer-review: Internally peer-reviewed.

\section{Authorship Contributions}

Surgical and Medical Practices: G.H.T., N.A., G.E., Concept: G.H.T., N.A., G.E., Design: G.H.T., N.A., Data Collection or Processing: G.H.T., N.A., Analysis or Interpretation: G.H.T., N.A., G.E., Literature Search: G.H.T., Writing: G.H.T., N.A.

Conflict of Interest: No conflict of interest was declared by the authors.

Financial Disclosure: The authors declared that this study received no financial support.

\section{References}

1. Urosevic M, Dummer R: Role of imiquimod in skin cancer treatment. Am J Clin Dermatol 2004;5:453-8.

2. Knabel P, Cleaver L: Arbor cutis: Hyperkeratotic plaque secondary to the use of imiquimod for the treatment of squamous cell carcinoma in situ. Dermatol Surg 2013;39:655-7.

3. Desai T, Chen CL, Desai A, Kirby W: Basic pharmacology of topical imiquimod, 5 -fluorouracil and diclofenac for the dermatologic surgeon. Dermatol Surg 2012;38:97-103.

4. Shimizu I, Cruz A, Chang KH, Dufresne RG: Treatment of squamous cell carcinoma in situ: A review. Dermatol Surg 2011;37:1394-411.

5. Patel GK, Goodwin R, Chawla M, et al.: Imiquimod 5\% cream monotherapy for cutaneous squamous cell carcinoma in situ (Bowen's disease): A randomized, double-blind, placebo-controlled trial. J Am Acad Dermatol. 2006;54:1025-32.

6. Mosher JS, Lio P: Cytokine dermatitis and febrile seizure from imiquimod. Pediatrics 2012;129:e519-22. 